\title{
Albinas PLĖŠNYS
}

Vilniaus universitetas

\section{Teisingumas ir dora socialinèje filosofijoje}

\begin{abstract}
Straipsnyje pirmiausia nagrinėjamas klasikinės teisingumo sampratos susiformavimas, teisingumo ir doros ryšys. Toliau aptariama liberalioji teisingumo samprata, daugiausia dèmesio skiriant Johno Rawlso suformuluotai procedūrinio teisingumo teorijai, kurią jis tapatina su politine filosofija. Tiek J. Rawlsas, tiek kiti liberalieji mąstytojai nesieja teisingumo sampratos su dorumu ir asmeniu, taigi aiškina teisingumą prasme, kuri priklauso ne bendruomeninių santykių kontekstui, o charakterizuoja tam tikrą teorijos ypatybę.
\end{abstract}

The article analyses the formation of classical conception of justice and emphasizes the relationship between justice and virtue. The liberal conception of justice is under consideration in this article as well. The main attention is paid to the theory of procedural justice by John Rawls which, according to him, is in general a political philosophy. J. Rawls and other liberal thinkers separate justice from an individual and from virtue. Thus, they use the conception of justice in the meaning which is related to particular characteristics of the theory rather than the context of social intercourse.

\section{Ivadas}

Kaune 1928 m. pagal architekto Edmundo Fryko projektą pastatytų didingų Teisingumo ministerijos ir Vyriausiojo tribunolo rūmų (dabartinès Kauno valstybinès filharmonijos) kolonados viršų puošè auksuotų raidžių užrašas lotynų kalba: JUSTITIA EST FUNDAMENTUM REGNORUM. Tai nuo Romos laikų žinomas posakis, kuris lietuviškai skambėtų daugmaž taip: „Teisingumas yra valstybès pagrindas“. Šių rūmų istoriją, kaip ir minètą užrašą, gerai prisimena senieji Kauno gyventojai. Neteko girdèti, kad kas nors mėgintų ji ginčyti ar jam prieštarauti. Priešingai, šiuo posakiu siekè remtis anų laikų jauna Lietuvos valstybè. Niekas nebando jo ginčyti ir dabar. Tačiau ịvairūs mąstytojai ir politikai sąvokos „teisingumas“ turinį supranta skirtingai, tarsi kalbètų visai kitomis kalbomis. Tyrimo objektas - ivvairių teisingumo sampratų turinys. Straipsnio tikslas atskleisti esminị sąvokos „teisingumas“ ryši su laisva asmens valia bei dorumu ir parodyti, kad liberaliose doktrinose, suardžius teisingumo ir doros ryši, teisingumo sąvoka praranda žmonių tarpusavio santykius reguliuojančio veiksnio prasmę ir niekaip negali būti politine filosofija, kaip to norètų Johnas Rawlsas; taip pat atskleisti, kad neretai ịrodinejjimuose ir tame pačiame kontekste sąvoka „teisingumas“ vartojama toli gražu ne ta pačia prasme. Darbe taikomas analitinis, interpretacinis ir aprašomasis tyrimo metodai. 


\section{Ankstyvoji teisingumo samprata}

Vienas iš pirmųjų socialinės ir politinès filosofijos veikalų - Platono „Valstybe““ - kaip tik skiriamas teisingumo problemai spręsti. Anot Platono, igyvendinusi teisingumą valstybė bus tobula, o visi žmogaus sielos pradai igis dorybes. Kodèl teisingumas toks svarbus valstybei? Jau pirmojoje „Valstybès“ knygoje, kurioje Platonas pateikia kasdienę teisingumo sampratą, jis atkreipia dėmesị $\mathfrak{i}$ tai, kad bendruomeniniai žmonių ryšiai susiklosto tik tada, kai žmonès elgiasi teisingai. Anot jo, „neteisingumas sukelia tarpusavio nesantaikas, vaidus, neapykantą, o teisingumas - santarvę ir draugystę “1. Be to, „neteisingumo galia tokia, kad vis tiek, kur jis atsiranda - valstybeje, gentyje, kariuomenejje ar kokioje kitoje bendrijoje, - pirmiausia padaro neįmanoma veikti sutartinai, nes sukelia nesantaiką ir vaidus, vidaus ir išorès priešiškumą, taip pat ir teisingo priešininko atžvilgiu“2. Valstybė yra tam tikra sutartinai veikianti žmonių bendruomenè, tad jei nebus teisingumo, nebus ir valstybès.

Platono nuomone, teisingas žmogus yra išmintingas ir geras, o neteisingas - neišmanèlis ir blogas. Iš tikrųjų, pasak jo, teisingumas yra žmogaus ypatybè. Jeigu žmonėms kenktume, jie pasidarytų blogesni žmogiškųjų ypatybių atžvilgiu, vadinasi, taptų ir neteisingesni. Teisingumu negalima padaryti žmonių neteisingų, lygiai kaip muzikantas muzika negali padaryti žmonių nemuzikalių. Todèl tik neteisingumas gali žmogų padaryti neteisingesnị. Savaime suprantama, kad kenkti yra blogo, o ne gero žmogaus ypatybè. Iš čia ir plaukia išvada, jog teisingas žmogus yra geras.

Toliau svarstydamas teisingumo problemą, Platonas ginčija tuo metu Atėnuose populiarių sofistų, kurių požiūrị perteikia Trasimacho lūpomis, nuomonę, kad teisingumas yra tai, kas naudinga stipresniajam. Anot Platono, valdovas, kiek jis yra tikras valdovas ir išmano valdymo meną, siekia ne savo asmeninès naudos, o visų pavaldinių gerovès, nes tokia meno prigimtis ir jo tikslas. Juk menas, kiek jis yra menas, neturi jokio trūkumo, jokios kliaudos, ir jam nereikia ieškoti to, kas naudinga, už savęs paties. Menas lieka nepažeidžiamas ir grynas, kol išsaugo savo nepriekaištingumą ir vientisumą. Pavyzdžiui, gydymo menas rūpinasi ne tuo, kas naudinga gydymo menui, o tuo, kas naudinga kūnui, ir kiekvienas menas rūpinasi ne tuo, kas jam pačiam naudinga, nes jam nieko nereikia, o tuo, kas naudinga jo objektui. Štai piemuo, kuris gerai gano avis, rūpinasi jų gerove, o ne kailiniais ar kepsniu. Pastaraisiais dalykais rūpinasi siuvejas ir kepejjas. Todèl Platonas apibendrina: „kiekviena valdžia, kaip valdžia, rūpinasi gerove ne kieno nors kito, o tik tų, kuriuos ji valdo ir globoja, vis tiek, ar tai bus valstybe, ar paskiras asmuo." ${ }^{3}$

Platonas nurodo dar vieną teisingumo bruožą, sieja jị su sielai būdinga veikla. Platono nuomone, siela turi būdingą paskirtị, kurios daugiau niekas negalètų atlikti - pavyzdžiui, teikti gyvybingumą, rūpintis, valdyti, svarstyti ir panašiai. Savo paskirtị siela gali gerai atlikti tik turèdama sau būdingas ypatybes. O teisingumas kaip tik ir yra, Platono manymu, tokia sielos ypatybė, kitaip negu neteisingumas, kuris susijęs su ydomis. Todèl teisingas žmogus gyvens gerai, o neteisingas - blogai. O tas, kuris gyvena gerai, yra laimingas. Vadinasi, teisingasis yra laimingas, o neteisingasis - nelaimingas. Šitaip samprotaudamas Platonas laikosi visai antikai (su nedidelemis išimtimis, tokiomis, kaip Demokrito atomų teorija ar skeptikų filosofija) būdingo požiūrio, kad kiekviena būtis, kiekvienas daiktas ar 
individas turi savą prigimtị, tai prigimčiai būdingą tikslo priežastị ir kad kiekviena būtis sąmoningai ar nesąmoningai to tikslo siekia.

Dialoge „Politikas“ Platonas klausia, kodèl atsiranda valstybės valdymo meno klaidos. Ir atsako: „argi ne dèl to, kas yra gèdinga, kvaila ir neteisinga. “4 Jeigu visi valstybès piliečiai laikytųsi teisingumo, tai nebūtų reikalingi ir įstatymai. Tam tikra prasme, teigia Platonas, ịstatymų leidyba yra dalis valdovų meno, tačiau visų geriausia, kai galią turi ne ístatymai, o protingas valdovas, nes ịstatymai negali tiksliai ir teisingai aprèpti to, kas yra geriausia kiekvienam. Juk žmonès tokie nepanašūs ir jų reikalai tokie skirtingi ${ }^{5}$. „Panašiai kaip vairininkas nuolatos rūpinasi laivo ir jūrininkų nauda, remdamasis ne rašytais nurodymais, o menu, kuris jam yra įstatymas, ir taip išsaugo kelionės draugų gyvybes, taip ir sumanių valdovų rūpesčiu išlaikoma teisinga valstybès santvarka, nes meno galiai teikiama pirmenybè prie îstatymus. “6 Deja, tobulai teisingi ir išmintingi yra tik dievai, todèl žemiškos valstybès negali išsiversti be įstatymų.

Kaip matyti, Platonas pabrèžia tokius svarbiausius teisingumo bruožus: pirma, teisingumas yra jungimosi ị bendruomenę pagrindas; antra, teisingumas susijęs su gèriu ir kartu su dora; trečia, teisingumas yra laimingo gyvenimo sąlyga; ketvirta, teisingumas yra valstybès valdymo meno, kuris pranašesnis už įstatymus, pagrindas.

\section{Klasikinès teisingumo sampratos formavimasis ir jos ryšys su dora}

Aristotelis irgi laikè teisingumą veiksniu, būtinu tam, kad bendruomenès funkcionuotų. Jis aptarè teisingumą „Nikomacho etikos“ penktojoje knygoje. Aristotelis nurodo turbūt svarbiausią teisingumo ypatybę, kurią vèliau perèmè Tomas Akvinietis ir visa krikščioniškoji socialinès filosofijos tradicija. Anot Aristotelio,

teisingais laikome veiksmus, kurių tikslas yra sukurti ir išsaugoti laimę ir visa, kas ją sudaro, visai piliečių bendruomenei. <...> Šia prasme teisingumas yra tobula dorybè, bet ne apskritai, o kito [piliečio] atžvilgiu. Todèl teisingumas yra laikomas didžiausia iš visų dorybių. <..> Ir priežodis sako: „Teisingumas - tai visos dorybès kartu“. Tai - itin tobula dorybè, nes ji yra betarpiškas tobulos dorybès pasireiškimas; ji yra tobula dèl to, kad tas, kuris ją turi, gali ją panaudoti ne tik sau pačiam, bet ir kito atžvilgiu ${ }^{7}$.

Tomas Akvinietis ir krikščioniškoji tradicija, plètodama šią Aristotelio mintị, kalba ne apie visų piliečių bendruomenès laimę, o apie bendrąji gèrị. Todèl, pritariant Johnui Finnisui ${ }^{8}$, galima tvirtinti, kad teisingumo reikalavimai yra konkrečios išvados iš pagrindinių praktinio supratingumo principų, kuriems asmuo teikia pirmenybę, puoselèdamas bendrąji gèrị savo bendruomenèje. Bendrąji gèrị reikètų suprasti kaip tokią bendradarbiavimo sąlygų visumą, kuri labiausiai padidina visų bendruomenès narių gerovę ir sudaro pačias palankiausias sąlygas kiekvienam žmogui tobulèti. Bendrasis gèris igyvendinamas tada, kai kiekvienas individas gali sèkmingiausiai siekti savo prigimtinio ir galutinio tikslo, kai sudarytos prielaidos kiekvienam žmogui tapti laimingam, išplètoti visas savo dvasines ir fizines jejgas. Aišku, kad bendrasis gèris nèra visų individų gèrių aritmetinė suma. Tai visai nauja kokybè. Josephas Höffneris teigia: 
Kiekvienai socialinei struktūrai, pvz., miestui arba universitetui, būdinga sava ypatinga visuotine gerovè [bendrasis gèris - A. P.]. Tačiau jeigu kalbama apie visuotinę gerovę apskritai, tai turima omenyje valstybès kaip „tobulos visuomenès" visuotiné gerovė, t. y. institucijų ir sąlygų visuma, leidžianti individui ir mažesnèms bendrijoms harmoningai sąveikaujant siekti Dievo norètos prasmès pilnatvès (asmenybès sklaidos ir kultūros kūrimo). ${ }^{9}$

Reikètų atkreipti dėmesi $\mathfrak{i}$ tai, kad bendrasis gèris galiausiai nukreiptas $\mathfrak{i}$ kiekvieno individo klestejjimą ir prigimties pilnatvę. Todèl pastangos siekti bendrojo gèrio, įtraukiant visus individus i bendrus sumanymus, gali tapti pragaištingos bendrajam gèriui, nors patys tie sumanymai ir būtų realizuoti. Ši klaida buvo būdinga komunistiniams ir fašistiniams režimams. Todèl svarbiausias teisingumo bruožas yra tas, kad bendrujų sumanymų negalima laikyti savaiminiais tikslais, o vien tik pagalbinėmis priemonèmis, būdais, sudarančiais sąlygas individams kurti save pačius.

Šią teisingumo sampratą, kurią Aristotelis sieja su visų dorybių visuma, galima pavadinti bendruoju teisingumu. Tačiau Aristotelis tiria ir „teisingumą kaip dalini dorybès pasireiškimą“. Anot jo,

visus kitus neteisingus veiksmus galime aiškinti kokia nors nedorybe, antai jei svetimoteriavo - ištvirkimu, jei paliko kovos draugą - bailumu, jei kitą sumušè pykčiu. Bet jei pasipelnè, neaiškinsime jokia kita nedorybe, o tik neteisingumu. Iš to aišku, kad šalia visiško neteisingumo, yra kitas - dalinis neteisingumas, kuris vadinamas taip pat, nes pagal apibrèžimą priklauso tai pačiai giminei ${ }^{10}$.

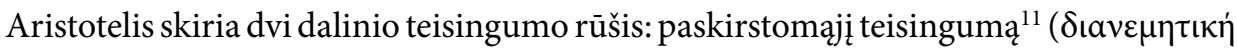

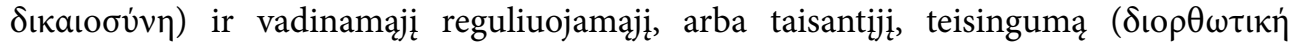

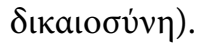

Aptardamas paskirstomąji teisingumą Aristotelis nurodo, kad savaime ir be ịrodymu aišku, kad tai, kas neteisinga, yra nelygu, o tai, kas teisinga - lygu. Tačiau, kaip jau anksčiau minèta, teisingumo tikslas yra bendrasis gèris (visų bendruomenès narių laimès išsaugojimas, pasak Aristotelio), o ne lygybẻ pati savaime. Vargu ar būtų pagrịsta manyti, jog visų bendruomenès narių gerovè padidès, jei visi bus laikomi vienodais, skirstant vaidmenis, progas ir išteklius. Pavyzdžiui, jei vaikų mokymui bendruomenè gali skirti tam tikrą ribotą išteklių kiekį, turbūt reikètų daugiau lèšų skirti ne turtingų, o neturtingų šeimų vaikams. Tik taip galètų būti iggyvendinta lygybe siekiant išsilavinimo. Tai Aristotelis ir aiškina:

jeigu tai, kas neteisinga, yra nelygu, tai, kas teisinga, bus lygu. <...> O jeigu tai, kas lygu, yra vidurys, ir tai, kas teisinga, bus tam tikras vidurys. Bet tai, kas lygu, numato bent du dalykus. Todèl tai, kas teisinga, būtinai turi būti ir vidurys, ir tai, kas lygu, be to, kieno nors atžvilgiu. Kaip vidurys jis turi būti viduriu tarp tam tikrų dalykų - tarp to, kas yra per daug, ir to, kas per mažai; kaip lygybè - dviejų dalykų lygybè, o kaip teisingumas jis turi būti teisingumu tam tikriems žmonèms.

Taigi tai, kas teisinga, numato bent keturis dalykus, nes yra du žmonés, kuriems jis yra tuo, kas teisinga, ir du dalykai, kurių atžvilgiu pasireiškia tai, kas teisinga. 
Lygybẻ bus ta pati ir žmonėms, ir dalykams, nes kaip tarpusavyje susiję dalykai, taip bus susiję ir žmonès. <...>

Taigi tai, kas teisinga, yra proporcinga. <...>

Matematikai tokią proporciją vadina geometrine, nes geometrinès proporcijos visuma taip santykiauja su visuma, kaip paskiras narys su kitu nariu. ${ }^{12}$

Antroji teisingumo rūšis, pasak Aristotelio, yra reguliuojamasis, arba taisantysis, teisingumas. Tai irgi tam tikra lygybè, bet ne pagal geometrinę, o pagal aritmetinę proporciją. Aristotelis teigia:

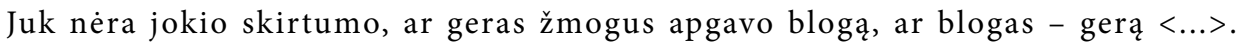
Istatymas atsižvelgia tik i padarytos žalos skirtumą, o abu dalyvius laiko lygiais, nepriklausomai nuo to, kad vienas nusikalto, o kitas nukentejjo, vienas padarè nuostolị, o kitas ji patyrè. Todèl teisejjas mégina šitą neteisingumą - lygybès pažeidimą - išlyginti. ${ }^{13}$

Taigi ši teisingumo rūšis suderina ir atitaiso nevienodumus, kurie iškyla individų tarpusavio susitarimuose. Čia, Aristotelio nuomone, ypač svarbus ištaisymas nelygybès, kuri atsiranda, kai vienas asmuo padaro žalą ir paima kažką iš kito, arba tada, kai viena grupe įvykdo savo sandèrio pusę, o antroji to nepadaro. Kaip pažymi J. Finnisas ${ }^{14}$, Tomas Akvinietis, siekdamas tiksliai interpretuoti Aristoteli, Aristotelio antrajai teisingumo rūšiai pavadinti sumąstè naują terminą - „komutatyvusis teisingumas“. Daugelis Tomo Akviniečio šalininkų suprato commutativa kaip susijusị su mainais. Tačiau terminas commutativo klasikinejje lotynų kalboje yra labai platus, ribojamas tik žmonių bendravimo srities konteksto. Todèl šis terminas tinka apibrèžti visai sričiai, kurioje kyla problema nusakyti, kokie sandoriai tarp asmenų yra teisingi. Nuo Tomo Akviniečio laikų bendrojo teisingumo, kaip paskirstomojo ir komutatyviojo teisingumo visumos, samprata i̇sigalejo kalbant apie socialines problemas.

Žinoma, laikui bėgant tomistinè teisingumo samprata šiek tiek keitėsi. Pirmiausia kardinolas Tommaso de Vio Cajetanas transformavo tomistinę teisingumo schemą, skirdamas paskirstomąji, komutatyvųji ir legatyvųji teisingumą. Pastarasis daugmaž atitiktų Aristotelio ir Tomo Akviniečio bendrajj teisingumą. T. de Vio Cajetano schema buvo paprasta ir aiški, todèl susilaukè nemaža šalininkų. Nuo XIX a. antrosios pusès vis plačiau pradedama vartoti socialinio teisingumo sąvoka. Tačiau visi šie teisingumo sampratos kitimai nepaveikè jo esmès. Be to, juos aiškinti nèra šio straipsnio tikslas.

Teisingumas kaip būdo kokybė visada yra praktinis pasiryžimas bendruomenëje pritarti bendrajam gèriui ir ji skatinti, o teisingumo teorija - tai teorija to, kas reikalinga bendrajam gèriui. Žinoma, toks praktinis pasiryžimas tiesiogiai susijęs su dorybingumu. Jau minèta, kad Aristotelis, tik pradėdamas aptarti teisingumą, vadina jị betarpišku tobulos dorybès pasireiškimu. $\mathrm{O}$ ir baigdamas teisingumo svarstymus vèl grị̌ta prie teisingumo ir gerumo sąsajos. Anot Aristotelio,

gerumas: tai - teisingumas, kuris geresnis už tam tikrą teisingumo atmainą. Iš to paaiškejja ir kas yra geras žmogus: jis pasirenka ir daro tai, kas yra teisinga, bet nèra pedantas, kuris smulkmeniškai tol siekia teisingumo, kol pagaliau teisingumas 
virsta neteisingumu; jis verčiau linkęs pasitenkinti mažesniu teisingumu, nors isstatymas ji remia, - toks yra geras žmogus, ir tokia nuostata vadinama gerumu tai yra tam tikra teisingumo atmaina, o ne skirtinga nuostata ${ }^{15}$.

Ne veltui ir Katalikų Bažnyčios mokymas pabrèžia, kad teisingumas yra viena iš keturių pagrindinių (kardinalių) dorybių, ant kurių tarsi durys ant vyrių laikosi dorinis gyvenimas.

Teisingumas, kaip moraline dorybè, yra pastovus ir tvirtas noras atiduoti Dievui ir artimui tai, kas jiems priklauso. Teisingumas Dievo atžvilgiu yra vadinamas „religingumo dorybe“; žmonių atžvilgiu jis verčia gerbti kiekvieno teises, o jų tarpusavio santykiuose pasiekti tokios darnos, kuri vienodai atsižvelgtų ì visus žmones ir jų bendrą gerovę. ${ }^{16}$

\section{Liberalioji įstatymų teisingumo, nesusijusio su dora, samprata}

Visai kitaip teisingumą supranta socialinio nominalizmo atstovai, taip pat ir šiais laikais populiariausios jo atmainos - liberalizmo - šalininkai. Jokių prigimtinių ar būdingų tikslų, jokių tikslinių priežasčių, jokių tikrųjų esmių ir panašių dalykų jie nepripažista. Visuomenè jiems - tai mechanizmas, o ne organizmas. Todèl, liberalų nuomone, bendrojo gèrio (arba gerovès) sąvoka yra neapibrèžiama. Pasak vieno žymiausių liberalizmo teoretiku, Nobelio premijos laureato Friedricho Augusto von Hayeko, bendroji gerovė „yra toji abstrakti visuminè tvarka, kuri nèra skirta žinomiems konkretiems tikslams, bet yra palaikoma kaip priemonè, individams leidžianti lengviau siekti savo îvairiausių tikslų "17. Galima pateikti pavyzdį apie kelių eismo taisykles. Jos vienodai galioja visiems eismo dalyviams, niekam nenurodo, kur reikia važiuoti, ir siekia sukurti tokias sąlygas, kad kiekvienas vairuotojas galètų kaip galima greičiau ir saugiai pasiekti reikiamą tikslą. Bendrasis gèris, kaip ji supranta F. A. von Hayekas, šiuo atveju yra galimybė greičiau ir saugiai pasiekti tikslą. Eismo taisyklès - tipiškas abstrakčių taisyklių pavyzdys. Tas pats tinka visoms abstrakčioms, tikslo nenurodančioms taisyklèms: bendrasis gèris - tai jų tinkamumas siekti įvairiausių individualių tikslų.

Neatsitiktinai F. A. von Hayekas savo veikalą pavadino „Socialinio teisingumo miražu“. Pirmiausia jis užsipuola paskirstomąji teisingumą. F. A. von Hayeko, o ir kitų liberalų manymu, visos paskirstymo schemos, visos visuomenés organizuotos tvarkos formos griauna laisvosios verslininkystès sistemą, trukdydamos jos plètrai.

Organizuotai tvarkai F. A. von Hayekas priešina spontaninę tvarką. Anot jo, visuomeninè tvarka, didinanti individualių veiksmų efektyvumą, atsiranda ne dèl to, kad tam tikros institucijos sugalvoja būdus, kaip tą efektyvumą padidinti, o dèl „proceso, iš pradžių vadinamo „augimu“, o vèliau „evoliucija“, kuriame praktinès veiklos schemos, iš pradžių priimtos dèl kitokių priežasčių arba net visiškai atsitiktinai, išliko todèl, kad jos padejo grupei, kurioje atsirado, ịveikti kitas grupes"18. Tokia savaime besiklostanti tvarka skiriasi nuo organizuotos tvarkos ne tik savo spontaniškumu. F. A. von Hayekas teigia:

Taisyklès, valdančios spontaninę tvarką, priešingai [negu organizuotos tvarkos taisyklès - A. P.], turi nepriklausyti nuo tikslų ir vienodai galioti visiems nariams 
arba bent jau individualiai neįvardytoms jų grupėms arba klasėms. Jos naudojamos pagal individų turimas žinias bei tikslus; tas naudojimas nepriklauso nuo kokio nors bendro tikslo, kurị individas turètų žinoti.

Kalbant mūsų terminais tai reiškia, jog bendros teisinès taisyklès, kuriomis grindžiama spontaninè tvarka, yra orientuotos ị abstrakčią tvarką, kurios specifinis arba konkretus turinys nèra niekam žinomas arba numatomas; o ịsakai ir taisyklès, kuriomis valdoma organizacija, tarnauja konkretiems organizacijos vadovų tikslams. ${ }^{19}$

Taigi, laikui bėgant, susiklosto įstatymų, kaip betikslių taisyklių, tinklas. Jeigu tokios betikslès taisyklès yra vienodos visiems žmonèms ir nė vienam neteikia privilegijų, galima tvirtinti, kad jos teisingos, aiškina F. A. von Hayekas. Kitaip tariant, jis ir jo šalininkai liberalai mano, jog teisingumas taikomas tik taisyklèms, o ne rezultatams. Aišku, tiksliai kalbant, tai įmanoma tik tada, kai turima savaiminè, bet ne organizuota tvarka. Pripažinus, kad įstatymai teisingi, nebegalima reikalauti ir rezultatų teisingumo. Jei visuomenèje, kuri vadovaujasi betikslių teisingų ịstatymų tinklu, vieni žmonės nuskursta, o kiti pralobsta, jie gali kaltinti tik save. Teisingumas šiuo atveju nepažeidžiamas. Priešingai, ji pažeidžia lygiava, nes teikia privilegijas neveikliems žmonėms.

Kadangi teisingumo sąvoka, anot F. A. von Hayeko, taikytina tik taisyklèms, prasminga kalbèti ne apie paskirstomąjj teisingumą, o apie taisyklių teisingumą. Visų socialinių taisyklių (kartu ir teisès) paskirtis - vienodai didinti visų visuomenės narių galimybes ${ }^{20}$. Kadangi tos taisyklès klostosi savaime, spontaniškai, ir ịsivyrauja pačios veiksmingiausios iš jų, filosofijai kaip ir nelieka ką veikti. Juk teisingos taisyklès yra ne tiek specialaus sumanymo, kiek savaime susiorganizuojančios tvarkos rezultatas.

Reikia pasakyti, kad kritikuodamas paskirstomojo teisingumo sampratą, kurią jis tapatina su socialiniu teisingumu, F. A. von Hayekas argumentuoja taip, kaip dare sofistai ragų paradokse ${ }^{21}$, t. y. keičia sąvokų turinius. Iš tikrųjų būdvardis „teisingas“ kalboje vartojamas ne viena reikšme. Pavyzdžiui, viena reikšmė yra teiginyje „teisinga, kad dukart du yra keturi“. Antra reikšmė teiginyje „teisinga yra tokia lažybų sistema, kurioje nè viena iš besilažinančių pusių iš anksto neturi pranašumo“. Trečia reikšmė teiginyje „jis buvo teisingas ir garbingas žmogus“. Ketvirta reikšmė teiginyje „šitas ịstatymas yra teisingas, o anas neteisingas“. Tokių reikšmių galima pateikti ir daugiau.

Būtent trečiąja reikšme žodis „teisingas“ vartojamas, kai kalbama apie teisingumo dorybę. Šio „teisingo“ niekaip negalima atskirti nuo asmens ryšio su kitais asmenimis. Klasikinėje teisingumo sampratoje tas ryšys aiškiai pabrěžiamas. Ketvirtąja reikšme žodis „teisingas“ vartojamas turint galvoje, kad žmogus, elgdamasis pagal neteisingą ịstatymą, pažeidžia teisingumo dorybę. Kadangi kalbama apie ịstatymo teisingumą, lengva susidaryti ịspūdị, jog teisingumo norma gali būti taikoma tiesiogiai įstatymams, neatsižvelgiant ị jų ryši su žmogaus dorumu. Taip, ịstatymai yra anonimiški, tačiau jais numanomas būtent individo elgesys. Tai rodo kad ir toks pavyzdys. Mes juk nesakome, jog šuva pasielgè neteisingai, suèsdamas maistą iš kaimynų šuns dubens ar ịkąsdamas geram mano draugui ị koją. Būtent tą numanymą liberalizmo šalininkai ir ignoruoja. Bet tai dar ne viskas. F. A. von Hayekas sudaro įspūdị, kad teisingumo sąvoką vartoja ketvirtąja 
reikšme, siedamas ją, kaip ịprasta, su trečiąja. Tačiau nieko panašaus nèra. Iš tikrųjų jis ją vartoja antraja reikšme, kaip teiginyje „ruletė yra teisingas žaidimas, nes negalima apskaičiuoti, išloši konkrečiu statymu ar praloši“. Šiuo atveju įmanoma sukurti matematinę teoriją (tokia yra lošimų teorija), kuri optimizuotų įstatymus ir leistų kurti vis „teisingesnes“ jų sistemas, o su dora, kaip ir su asmeniu, toks „teisingumas“ turi mažai ką bendra, kaip mažai ką bendra turi su visuomenès narių tarpusavio santykiais ir socialiniu teisingumu plačiaja prasme.

Visos nurodytos keturios teisingumo reikšmès vartotinos kalbiniuose kontekstuose, tačiau nedera tų reikšmių painioti, nedera, pasinaudojus ketvirtosios reikšmės numanomu, bet tiesiogiai nesireiškiančiu ryšiu su trečiąja, keisti trečiąją i antrąją ir vaizduoti, jog nieko neatsitiko.

\section{J. Rawlso procedūrinio teisingumo interpretacija}

F. A. von Hayeko pasiūlyta teisingumo interpretacija vyravo iki pat septintojo XX a. dešimtmečio, kai pasirode ižzymusis J. Rawlso veikalas „Teisingumo teorija“. J. Rawlsas siūlo dar vieną teisingumo teorijos variantą - procedūrinio teisingumo teoriją. Pagal šią teoriją teisingumo principus teisingais daro ne jų pačių savybès, o būdas, kuriuo jie nustatomi, t. y. teisingumas susijęs ne su taisyklèmis, o su jų nustatymo būdu. Anot J. Rawlso, visuotinai pripažinti principai bus teisingumo principai tada ir tik tada, kai jiems visi pritars su sąlyga, jog derybiné pozicija yra sąžininga. J. Rawlso nuomone, procedūrinio teisingumo teorija nèra atskira politinès filosofijos tema, tai ir yra politine filosofija, nes gerai sutvarkytoje visuomenèje visų vertybių, išskyrus teisingumą, turi būti siekiama vadovaujantis teisingumo principu. Antra, jeigu žmonès veikia pagal teisingumo reikalavimus, tai jie, o ne valdžia turi spręsti, kokius tikslus jiems iggyvendinti, kuo tapti ir kaip nugyventi gyvenimą. Kartą nustačius ir apgynus tinkamus teisingumo principus, visa kita yra asmeninès etikos, o ne politinès filosofijos dalykas ${ }^{22}$.

J. Rawlso teisingumo teorijos principus galima paaiškinti remiantis Jánoso Kiso ${ }^{23}$ atlikta teisingumo teorijos rekonstrukcija. Pasak J. Rawlso, teisingo paskirstymo problemą gali padèti suprasti procedūrinio teisingumo teorijos, nes tik jos analizuoja visuomenès pamatinę struktūrą, o ne atskirus, individualius veiksmus. Pamatinè struktūra yra normų ir procedūrų, reguliuojančių individualius žmonių veiksmus, tinklas. Kaip jis klostosi?

Žmonès siekia veikti bendrai, nes iš tokio veikimo tikisi daugiau naudos, negu veikdami atskirai. Tačiau nauda, atsiradusi iš bendro veikimo, gali būti paskirstyta labai nevienodai. Kokios skirstymo procedūros yra teisingos? Tarkime, kad kooperacinę sistemą sudaro laisvi, savarankiški ir racionalūs, galintys suprasti, kokia kooperacijos schema jiems naudingiausia, individai. Kad egzistuotų bent minimali sąlyga individui priimti jam naudingą sprendimą, tokioje bendrijoje kiekvienas individas privalo turèti veto teisę: kol visi individai nepripažįsta, kad sprendimas A pranašesnis už visas jo alternatyvas, sprendimas nę̨sigalioja, ir paieškos tęsiasi toliau. Ši sąlyga vadinama vieningumo sąlyga. Kai ji patenkinta, kooperacija visiems dalyviams teikia naudą, nes joks racionalus individas nepritars paskirstymo schemai, jeigu galès prisidèti prie palankesnès kitos bendruomenès schemos arba gaus daugiau naudos veikdamas vienas. 
Gali pasirodyti, kad vieningumo sąlygos ir racionalaus pasirinkimo teorijos pakanka, norint paskirstyti veiklos rezultatus. J. Rawlsas taip nemano. Jo nuomone, abipusè nauda dar neduoda moraliniu požiūriu geriausio rezultato. Jei, tarkime, vienas iš dviejų derybininkų gyvybiškai suinteresuotas susitarti ir sutiktų kooperuotis, jei gautų bent 10 proc. laukiamo pelno, o antrasis derybininkas yra daug mažiau priklausomas nuo derybų baigties ir jam susitarimo rezultatas nèra toks svarbus, tai greičiausiai bus susitarta naudą dalytis santykiu, artimu 1:10. Bet tokia derybų baigtis vargu ar patenkins intuityvias sąžiningų derybų sąlygas. Tad, anot J. Rawlso, teisingumas nèra igyvendintas, jeigu kooperacijai pritariantys žmonès renkasi sąžiningai nepaskirsčius derybų išteklių.

Kadangi žmonès sugeba spręsti apie savo veiklos pasekmes, jie patys atsakingi už neatliktus arba blogai atliktus veiksmus. Todèl moraliniai principai nèra pažeidžiami, jei asmuo naudojasi pranašumais arba patiria netektis, kai tie dalykai yra nulemti jo pasirinkimo ir pastangų. Tačiau gèrybių pasiskirstymas, kuriam įtaką daro nuo asmeninių pasirinkimų bei pastangų nepriklausantys veiksniai, yra morališkai nesąžiningas. Tokie pranašumai gali būti klasine padètis, šeimos statusas ir pan. Jiems J. Rawlsas priskiria ir igimtus talentus bei trūkumus. Jo teigimu, pirminè pozicija bus sąžininga tik tuo atveju, kai nepelnytos nelygybės apraiškos nedarys ịtakos derybų procesui. Tad vienintelè galimybè pasiekti pirminę sąžiningą poziciją yra dalyvių gaunamų žinių ribojimas. Sutarties šalys turi tartis už nežinojimo uždangos.

Vis dèlto nežinojimo uždanga kelia tam tikrų problemų. J. Rawlsas mano, kad pirminèje pozicijoje už nežinojimo uždangos patenka ne tik žinios apie paveldètą socialinę padètị ir igimtus talentus, bet ir žinios apie asmens psichologines savybes bei konkrečias tinkamo gyvenimo sampratas. Tačiau jei sprendejjai nieko neišmano apie būsimas vertybes ir prioritetus, kaip iš viso gali rinktis? J. Rawlsas daro prielaidą, jog yra tam tikros būtinos priemonès, vadinamosios pirminès gèrybès, kurių reikia siekiant kiekvieno ịsivaizduojamo tikslo. Tos priemonès būtinos, kad individai galètų gyventi visuomenèje, siekti savų tikslų ir patenkinti gyvybinius poreikius. Tam tikras pirmines gèrybes: sveikatą, protinius sugebejjimus, vaizduotę ir kt., teikia gamta. Kitas - teises ir laisves, galimybes ir galias, pajamas bei turtą, socialinès savigarbos priemones ir pan., teikia visuomenè. „Teisingumo teorijoje“ aiškinama, esą racionalus asmuo, kad ir kokie būtų visi kiti jo norai, būtinai norès ir šių pirminių gèrybių. Be to, jis bus visada racionalus, trokšdamas daugiau, o ne mažiau pirminių gèrybių.

Dabar aptartos beveik visos prielaidos, svarbios rinkimuisi. Žinomos besirenkančių asmenų savybès - jie yra racionalūs sprendèjai, optimizuojantys savo asmeninius prioritetus; žinoma jų informacinè aplinka - jie renkasi už nežinojimo uždangos, ir žinomas jų svarbiausias siekis - tai pirminių gèrybių paketas. Turint šiuos duomenis, anot J. Rawlso, galima numanyti, kokie bus pasirinkti teisingumo principai. Tarkime, kad individui siūloma rinktis vieną iš dviejų strategijų - A arba B. Jeigu jis pasirinks A strategiją, sèkmès atveju gaus daugiau negu pasirinkęs B, tačiau nesėkmès atveju daugiau ir praras. Būdamas už nežinojimo uždangos, jis negalès nustatyti, ką patirs - sèkmę ar nesėkmę. Linkęs i riziką asmuo rinksis A strategiją, o atsargus individas - strategiją B. O kokia strategija iš tikrųjų yra išmintinga, jei asmenys už nežinojimo uždangos negali nustatyti galimų baigčių tikimybių? J. Rawlso nuomone, tokiu atveju racionalu vadovautis maksimino 
principu - rinktis iš skirtingų galimybių tokią, kurios blogiausia baigtis mažiausiai bloga. Remdamasis šiais samprotavimais, J. Rawlsas suformuluoja du teisingumo principus: 1) visi asmenys turi lygias teises ị visiškai pakankamą lygiụ pamatinių laisvių sistemą, kuri yra suderinama su panašia laisvių visiems sistema; 2) socialinè ir ekonominè nelygybe turi tenkinti dvi sąlygas. Pirma, ji turi būti susijusi su pareigomis ir padètimi, kurias galètų užimti visi, esant nešališkai galimybių lygybei. Antra, ji turi būti naudingiausia blogiausioje padètyje esantiems visuomenès nariams.

Aiškindamas pirmąji principą, J. Rawlsas atkreipia dèmesį, kad teisingumo samprata būtinai yra susijusi su asmeniu, į ką ankstesni liberalai, taip pat ir minètas F. A. von Hayekas, neatkreipe dèmesio ${ }^{24}$. Antra vertus, kooperacija juk visada vyksta dèl abipusės naudos, todèl, anot J. Rawlso, būtinai susiduriama su dviem jos bruožais: privalo būti vienodas sąžiningų kooperacijos sąlygų supratimas ir, antra, kiekvienas individas turi suprasti, kas yra nauda jam. Be šiu sąlygų kooperacija, J. Rawlso nuomone, nęmanoma. Platonas, kaip minèta, mane, kad bendruomeniškumo pagrindas yra teisingumas, o J. Rawlsas pirmiausia pabrèžia naudą ir bendrą sąžiningumo sampratą. Jeigu kooperacija įmanoma, tai, J. Rawlso manymu, žmogui turi būti būdingos dvi moralinès galios: 1) gebẻjimas suprasti, kas yra gèris, 2) gebėjimas jausti, kas yra teisumas ir teisingumas ${ }^{25}$. Pirmoji galia reiškiasi individui keliant asmeninius tikslus ir jų siekiant. Kiekvienas individas, J. Rawlso nuomone, gali turèti savaji gèrio supratimą, kad ir koks jis būtų. Tuo tarpu gebejjimas jausti, kas yra teisumas ir teisingumas arba, kitaip tariant, sąžiningos kooperacijos sąlygos, turi būti bendras. J. Rawlsas tvirtina, jog svarbiausia liberalizmo prielaida yra ta, kad lygūs piliečiai turi skirtingas ir išties nepalyginamas bei nesuderinamas gèrio sampratas ${ }^{26}$. Gebėjimą jausti, kas yra teisingumas, J. Rawlsas vadina protingumu, o gèrio sampratos turèjimą - racionalumu.

Aptardamas teisingumo principus, jis siūlo iš galimų alternatyvių teisingumo principų rinktis tą, kuris visiems garantuoja vienodą sąžinès laisvę. Antra, J. Rawlsas teigia, jog pastoviausia teisingumo samprata yra tokia, kurią apibrěžia du teisingumo principai, ir taip yra todèl, kad šie principai nustato pamatines laisves ir lemia jų prioritetą ${ }^{27}$. O pamatinès laisvès, anot J. Rawlso, skatina nesuderinamų gèrio sampratų susidarymą ir plètoja teisingumo sampratą, kitaip tariant, kuria ir stiprina abi moralines individo galias $^{28}$.

\section{Išvados}

Jei liberalai teisingumo tyrimo iki J. Rawlso „Teisingumo teorijos“ iš viso nelaike reikšmingu, tai vèliau, sekdami J. Rawlsu, mano, kad procedūrinio teisingumo teorija yra pati politinè filosofija. Bet ar pagrịsti J. Rawlso lūkesčiai? Su tuo vargu ar galima sutikti.

Pirma, J. Rawlsas savo teisingumo teorijoje atskiria dvi vadinamąsias "moralines“ galias, kurios, jo nuomone, yra savarankiškos. Individuali gèrio samprata, anot jo, nedaro jokios ittakos bendrai teisingumo supratimo galiai, o teisingumas, kuri J. Rawlsas sieja su sąžinès laisve ir pamatinių laisvių garantija, stiprina abi minètas galias - gebèjimą suprasti gèị ir jausti teisingumą. Taigi J. Rawlsas, kaip ir jo pirmtakai ankstesnieji liberalai, atskiria teisingumą nuo individualaus dorumo. Jo manymu, kiekvienas gali turèti 
savąją gėrio sampratą, o teisingumą visi visuomenès nariai turi suprasti vienodai. „Teisingumo teorijoje“ J. Rawlsas kaip tik ir pateikia tokią visiems racionaliems asmenims, jo nuomone, priimtiną teisingumo sampratą.

Vis dèlto kyla pagrịstas klausimas, ar tikrai įmanoma pasiekti visuomenejje sutarimą dèl teisingumo sampratos. J. Rawlso planą būtų ịmanoma igyvendinti tik tuo atveju, jei teisingumas iš tikrųjų nepriklausytų nuo doros ir prie jo bendros sampratos būtų prieita remiantis loginiais argumentais. Tačiau tada tektų ịtikinti teisingumo kaip dorumo šalininkus, kad jie pakeistų savo nuomonę ir taptų liberalizmo šalininkais, o tai neįmanoma. Issivaizduokime, kad žmogus yra ịsitikinęs, jog su velniu neverta sudaryti sutarties, kad ir ką tas žadètų. J. Rawlsas ịsitikinęs, kad jis puikiausiai įtikintų dorą krikščionį tokią sutartị sudaryti.

Šiame straipsnyje aptartus požiūrius galima apibūdinti posakiu „Neik su velniu obuoliauti - paliksi be obuolių ir be maišo“. Taip sako liaudies išmintis ir klasikinè tradicija, nes verta bendrauti tik su doru partneriu. „Gali drąsiai eiti, tik susitark dèl sutarties principų, nes kiekvienas gali turèti savąji gèrio supratimą“, - ginčija liaudies išmintị liberalai. „Žinoma, galima drąsiai eiti obuolių, - seniesiems liberalams antrina J. Rawlsas, pakanka susitarti dèl sutarties sudarymo procedūrų." Tik ar tikrai pavyks susitarti... Tik ar tikrai itikina liberalioji retorika...

Antra, net ir pirmąją „moralinę“ J. Rawlso galią (individualaus gèrio sampratą) vargu ar pagrịsta siekti su dora. Klasikinè tradicija gèrị (pirmiausia moralinị) siejo su valia, gèriu laikydama tai, ko kiekviena valia geidžia kaip savo tikslo. Bonum est quad omnia appetunt. Nuo Švietimo filosofijos laikų vis labiau ịsigali požiūris, gèrị siejantis su patyrimo rezultatais, veiklos pasekmėmis, juslinėmis patirtimis, nauda. Panašiai žmogiškajji elgesị antikoje aiškino primityvieji sokratikai, kirèniečių hedonistinės mokyklos atstovai. Laikantis utilitarinio ar hedonistinio požiūrio, nebešokiruoja ir tvirtinimas, kad kiekvienas gali turèti savąją gèrio sampratą. Argi blogai, kad aš noriu nãmo, o mano draugas prabangaus automobilio? Gèris paverčiamas skonio dalyku, o dèl skonio nesiginčijama, kaip tvirtina patarlè. Bet argi tai iš tikro yra moralinis gèris? Turbūt ne. Nuo Švietimo filosofijos laikų retas j̨žymus filosofas (pavyzdžiui, Immanuelis Kantas, Ludwigas Wittgensteinas) moralinio gèrio sąvoką siejo su valia.

Trečia, J. Rawlsas priima Johno Stuarto Millio pilietinès laisvès sampratą (laisvè - tai galimybė kiekvienam siekti savojo gèrio savo pasirinktu būdu, kol nemèginama atimti iš kitų jų gèrị arba trukdyti jų pastangoms ji igyti), ignoruodamas valios laisvę ir priskirdamas pilietinei laisvei tą savybę, kurią jai priskyrė J. S. Millis. T. y. tai, kad laisvė yra pakankama visos visuomenès ir kiekvieno individo pažangos, klestejjimo bei kooperavimosi prielaida. J. Rawlsas tvirtina, jog laisvè stiprina abi asmenybės „moralines“ galias ir taip tampa kooperavimosi prielaida, bet šio tvirtinimo, kuris yra labiau nei abejotinas, neįrodo, lygiai kaip laisvès savybès tobulinti visuomenę ir individą neįrodo J. S. Millis. Ir J. S. Millio, ir J. Rawlso prielaidos toli gražu nèra akivaizdžios. İdomu, ar tikrai geriausias metodas išmokti daugybos lentelę būtų aiškinimas, kad dukart du gal lygu trims, o gal penkiems, o gal keturiems, žodžiu, dèl to galima ginčytis, o ginčuose gims tiesa? Pirmykštėse bendruomenèse laisvès, J. S. Millio pasiūlyta prasme, yra tikrai ne mažiau nei šiuolaikinèse demokratijose, bet ar išties jų pažanga sparti? 
Ketvirta, daugelis bendrojo gèrio aspektų nebūtinai priklauso konkretaus individo gèrio sampratai, todèl individas nebūtinai norès kurti kooperacinị darinị, igyvendinantị tikslą, kurị jis laiko nesvarbiu. Pavyzdžiui, ne kiekvienas visuomenès narys vertins mokslą, meną ar dorą. O ir kaip išmatuosi naudą, kurią, pavyzdžiui, teikia vaikų mokymas ir visapusiškas lavinimas. Priešingai, tai gana brangus užsièmimas. J. Rawlso kooperatyvas turès daug investuoti, o grąža vargu ar bus akivaizdi. Kita vertus, ar tikrai atitiks intuityvius teisingumo reikalavimus, kuriuos ne kartą mini J. Rawlsas, nuostata, jog tik susipratusių tèvų vaikai galès siekti mokslo? Tokių pavyzdžių galima nurodyti ne vieną.

Penkta, nors J. Rawlsas kalba apie asmens svarbą teisingumo sampratai formuotis, teisingumą jis vis dèlto atskiria nuo asmens. Jei ankstyvesni liberalai kalbejo apie taisyklių teisingumą, tai J. Rawlsas ir jo sekèjai kalba apie procedūrų teisingumą. O tinkamiausias procedūras galima nustatyti pasitelkus loginę teoriją, vadinasi, tai yra spekuliatyvaus mąstymo problema. Taigi visiems vienoda teisingumo samprata lyg ir neturètų kelti didesnio rūpesčio. O tada visi priekaištai, kurie tiko F. A. von Hayeko teisingumo sampratai, tinka ir procedūrinio teisingumo teorijoms.

Galiausiai J. Rawlso teisingumo teorija, kaip ir ankstesniojo liberalizmo teisingumo teorijos, teisingumo terminą vartoja ne kaip socialinių santykių charakteristiką, o kita mūsų nurodyta antrąja prasme (kaip tam tikrą teorijos charakteristiką). Na, o toks „teisingumas" tikrai negali būti valstybès pagrindas.

Matyti, kad pastangos sukurti teisingumo teoriją, nepagrịstą moralès principais, yra bergždžios. Lygiai kaip XIX a. bevaisès buvo pastangos sukurti amžinąji variklị, todèl Prancūzų mokslų akademija iš viso atsisake svarstyti tokius projektus, kaip prieštaraujančius energijos tvermès dèsniui. Panaši situacija klostosi ir teisingumo teorijų srityje. Teisingumo, kaip valstybès pagrindo, svarstymai būtinai pateks i aklavietę, jei teisingumas bus atskirtas nuo doros.

\section{NUORODOS}

$1 \quad$ Platonas. Valstybè. Vilnius: Mintis. 1981. 351d. Čia ir toliau cituojant nurodoma atitinkamo Platono veikalo vieta pagal ịprastus tarptautinius žymèjimus.

2 Ten pat. 352 a.

3 Ten pat. $345 \mathrm{e}$.

4 Politikas. 296e.

5 Ten pat. 294 b.

6 Ten pat. 297 a.

7 Aristotelis. Rinktiniai raštai. Vilnius: Mintis. 1990. P. 146, 1129b. Čia ir toliau nurodoma Aristotelio veikalo vieta pagal ịprastus tarptautinius žymèjimus.

$8 \quad$ Finnis J. Natural Law and Natural Rights. Oxford: Clarendon Press. 1996. P. 164.

9 Höffneris J. Krikščioniškasis socialinis mokymas. Vilnius: Aidai. 1996. P. 46.

10 Nikomacho etika. 1130a // Aristotelis. Rinktiniai raštai. Ten pat.

11 Profesorius Jonas Dumčius „Nikomacho etikoje“ ši teisingumo variantą verčia „dalijančiuoju teisingumu“ (žr. Aristotelis. Rinktiniai raštai. Ten pat. P. 152). Tačiau lietuviškoje teisinèje literatūroje įsitvirtino kitas terminas - „paskirstomasis teisingumas“, atsiradęs, matyt, verčiant iš lotyniškojo

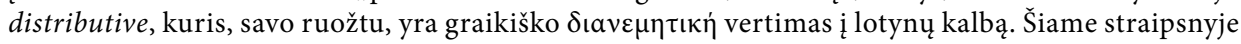
vartojamas iprastas „paskirstomojo teisingumo“ terminas. 
12 Nikomacho etika. 1131a - 1131b // Aristotelis. Rinktiniai raštai. Ten pat.

13 Ten pat. $1132 \mathrm{a}$.

14 Finnis. Ten pat. P. 179.

15 Nikomacho etika. 1138a // Aristotelis. Rinktiniai raštai. Ten pat.

16 Katalikų Bažnyčios katekizmas. Kaunas: LKB TKK leidykla. 1996. Nr. 1807.

17 Hayek von F. A. Teisè, ịstatymų leidyba ir laisvè. T. II. Socialinio teisingumo miražas. Vilnius: Eugrimas. 1998. P. 20.

18 Hayek von F. A. Teisè, ìstatymų leidyba ir laisvè. T. I. Taisyklès ir tvarka. Vilnius: Eugrimas. 1998. P. 24.

19 Ten pat. P. $80-81$.

20 Hayek von F. A. Teisè, įstatymų leidyba ir laisvè. T. II. Socialinio teisingumo miražas. Ten pat. P. 200.

21 Turimas galvoje megariečių mokyklos atstovų, veikiausiai Eubulido, suformuluota antinomija: tai, ką nepametei, turi. Tu nepametei ragų. Vadinasi, turi ragus. Čia žodis „nepametei“ vartojamas daugiaprasmiškai.

22 Šiuolaikinè politinè filosofija / sud. J. Kis. Vilnius: Pradai. 1998. P. 12-13.

23 Ten pat. P. 12-25.

24 Rawls J. Politinis liberalizmas. Vilnius: Eugrimas. 2002. P. 320.

25 Ten pat. P. 321.

26 Ten pat. P. 323.

27 Ten pat. P. 333.

28 Ten pat. P. 347.

\section{LITERATŪRA IR ŠALTINIAI}

1. Aristotelis. Rinktiniai raštai. Vilnius: Mintis. 1990.

2. Finnis J. Natural Law and Natural Rights. Oxford: Clarendon Press. 1996.

3. Hayek von F. A. Teisè, įstatymų leidyba ir laisvè. T. I. Taisyklès ir tvarka. Vilnius: Eugrimas. 1998.

4. Hayek von F. A. Teisè, įstatymų leidyba ir laisvè. T. II. Socialinio teisingumo miražas. Vilnius: Eugrimas. 1998.

5. Höffneris J. Krikščioniškasis socialinis mokymas. Vilnius: Aidai. 1996.

6. Katalikų Bažnyčios katekizmas. Kaunas: LKB TKK leidykla. 1996.

7. Platonas. Valstybè. Vilnius: Mintis. 1981.

8. Pléšnys A. Socialinès filosofijos pagrindai. Vilnius: Vilniaus universiteto leidykla. 2010.

9. Rawls J. Politinis liberalizmas. Vilnius: Eugrimas. 2002.

10. Šiuolaikinė politinė filosofija / sud. J. Kis. Vilnius: Pradai. 1998.

Gauta: 20121210

Parengta spaudai: 20130221

\section{Albinas PLĖŠNYS}

\section{JUSTICE AND VIRTUE IN SOCIAL PHILOSOPHY}

S u $\mathrm{m} m$ ary

Plato's Republic was one of the earliest works in the field of social and political philosophy investigating the problem of justice. According to Plato, injustice that has the tendency to arouse hatred, whether among slaves or freemen, makes them hate one another and sets them at variance and renders them incapable of the 
common action. Thus, justice is a necessary condition for the common action. Moreover, the just have turned out to be wise and good and the unjust are evil and ignorant. Justice is the excellence of the soul, and injustice is the defect of the soul. Hence, the just soul and the just man will live well, whereas the unjust man will lead an ill life. Then, he who lives well is blessed and happy, and he who lives ill is unhappy.

Aristotle attached the same importance of justice to communal life. He investigated the problem of justice in his fifth book of Nicomachean Ethics. According to Aristotle, actions that tend to create and preserve happiness and its components in a political society are just. Moreover, justice encompasses every virtue. And it is a complete virtue in the true sense of the word, because it is an actual manifestation of a complete virtue. It is complete because he who possesses it can exercise his virtue not only in himself, but also towards his neighbour. Aristotle divided the whole field of the problems of justice into two broad classes. He attributed the problems of distributive justice to the first class and explained them as problems that deal with whatever pertains to the community as common but divided equally among its members. The problems of corrective justice, the justice that rectified or remedied inequalities, which arose in dealings between individuals, were assigned to the second class. Later Thomas Aquinas, trying to interpret Aristotle faithfully, silently shifted the meaning of Aristotle's second class of particular justice and invented a new term for it: 'commutative justice'.

Different understanding of justice is characteristic of the followers of social nominalism, as well as of their most popular representatives - the liberals. According to them, 'common good' is a concept without any content because each and all theories of distributive justice are incorrect. Justice has been applied not to the results of an action but only to the set of aimless rules. It is clear that such understanding of justice has nothing to do with virtue. In this case, however, justice has a different meaning from that in the classical theory of justice. According to Aristotle and Plato, justice was a necessary condition of the common action, i. e. virtue of an individual, which helped him to communicate with others. The liberals give another meaning to the concept of justice, using it as some characteristic of the rules. For example, it is clear that the word 'justice' (or 'just') does not have the same meaning in the following proposition 'Justice is the basis of authority' and in the proposition 'this gambling is just for everybody who participates in it because each participant has an equal chances to win'.

The new concept of justice was proposed by John Rawls. The theory of justice is of no importance to liberal political philosophy until the works of Rawls appeared. He began to consider the theory of procedural justice as actual political philosophy. Rawls distinguished two moral powers of people in his theory: capacity for a sense of justice and their capacity for the conception of good. The conception of good may be different for every individual, but a sense of justice should be common to all citizens. Rawls believed that individuals with a different understanding of justice could reach agreement in this question. Tpossible because there are those who believe in the relation between justice and virtue and that conceptions of good do not derive from logical principles. According to Rawls, basic rights and liberties and their priority - the first and main principle of justice - are a guarantee of equal social conditions which are essential to all citizens for their adequate development and for the formation of their two moral powers. This requirement is not new. More than a hundred years ago John Stuart Mill proposed the definition of civil or social liberty as the possibility of pursuing our own good in our own way, as long as we do not attempt to deprive others of theirs, or impede their efforts to obtain it. According to him, social liberty is a basic condition of progress and health of an individual and society. Rawls accepted this principle and trusted it. However, Mill's idea is obviously incorrect. Consequently, all explanations of procedural justice of Rawls are incorrect either.

PAGRINDINIAI ŽODŽIAI: bendrasis gèris, dora, procedūrinis teisingumas, paskirstomasis teisingumas, komutatyvusis teisingumas, laisvè, liberalizmas.

KEY WORDS: common good, virtue, procedural justice, distributive justice, commutative justice, liberty, liberalism.

Albinas PLÉŠNYS - humanitarinių mokslų daktaras, Vilniaus universiteto Filosofijos katedros profesorius. Adresas: Girinio g. 8, 08401 Vilnius. El. paštas albinas.plesnys@fsf.vu.lt.

Albinas PLE்ŠNYS - PhD in Humanities, Prof. at Philosophy department, Faculty of Philosophy, Vilnius University. Address: Girinio g. 8, 08401 Vilnius. E-mail: albinas.plesnys@fsf.vu.lt. 